\title{
VISSZA A POLITIKATUDOMÁNYBA
}

\author{
Papp Zsófia \\ MTA TK Politikatudományi Intézet
}

Bíró-Nagy András: Integráció Európába.

Közép-európai képviselók az Európai Parlamentben.

Budapest, Gondolat Kiadó - MTA TK PTI, 2018, 230 p.

Az Európai Unióval és annak intézményeivel foglalkozó kutatások az elmúlt évtizedekben a politikatudomány mostohagyermekeinek számítottak. A politikatudomány (Political Science) és a nemzetközi kapcsolatok (International Relations) intézményes szétválasztása nem kedvez az EU-hoz kapcsolódó témák megjelenésének a politikatudomány főáramában. Nemcsak az elkülönülő tanszékek, folyóiratok, szakmai társaságok, hanem a másfajta olvasottságú olvasóközönség miatt is: értő fülek hiányában nehéz az EU-ról beszélni a fő́amún politikatudomány terminusaiban. Bíró-Nagy András magabiztosan küzdi le ezt az akadályt, és hozza vissza az Európai Uniót a politikatudományba.

Az Európai Parlament az Európai Unió egyik legdinamikusabban változó intézménye, amely a 80-as évek közepe óta jelentős szerepkörbővítésen esett át (Follesdal-Hix, 2006). Mindez összhangban van az Unión belüli demokrácia-deficit csökkentésére irányuló erőfeszítésekkel (Lodge, 1994; Williams, 1991), melyek éppen az EP szerepének növelésében látták az EU demokratizálását. Világos tehát, hogy az Európai Parlament vizsgálata és múködésének megértése kulcsfontosságú akkor, ha meg akarjuk érteni az Európai Unió múködését. Azonban ahhoz, hogy megértsük egy intézmény - jelen esetben az Európai Parlament múködését, „,szükség van azok vizsgálatára is, akiknek cselekedetei tartalommal töltik meg az intézményi struktúrákat" (Bíró-Nagy, 2018: 15.). Ebból kiindulva, Bíró-Nagy András az európai parlamenti képviselőkrôl szóló tudományos irodalomra épít, és új empirikus eredményekkel egészíti ki a zömében az EU15-ökről szóló ismereteinket azáltal, hogy vizsgálatának középpontjában a 2004-ben csatlakozó közép-európai országok (Csehország, Lengyelország, Magyarország, Szlovákia, Szlovénia) EP-képviselői állnak. Milyen szerepeket töltenek be a középeurópai EP-képviselók az Európai Parlamentben? Mi befolyásolja a különbözó szerepek kialakulását? Milyen következményekkel járnak ezek a szerepek az EP-képviselók tevékenységeire nézve? Bíró-Nagy könyve ezekre a kérdésekre keres és talál választ. 
Bíró-Nagy kutatása neoinstitucionalista elitkutatásnak számít abban az értelemben, hogy az intézményi szabályok rengetegében eligazodni vágyó aktorokat állítja a fókuszba, akik részben stratégiai megfontolások mentén (Strøm, 1997), részben személyes preferenciáiknak (Searing, 1994) megfelelően alakítják ki szerepfelfogásukat. A szerző remekül ötvözi az EP-képviselők profiljával foglalkozó kutatások megközelítéseit (Jahr-Edinger, 2015), és egyszerre vizsgálja a képviselők (1) társadalmi-demográfiai hátterét, karrierútját, politikai szocializációját, (2) szereporientációit és (3) aktivitását. A felhasznált adatok tekintetében a képviselők hátteréról az életrajzok alapján összeállított adatbázisra, a képviseleti szerepekről kérdőíves felmérésekből származó adatokra, a képviselők tevékenységeire vonatkozóan pedig a Votewatch adataira épít. A kérdőíves adatok két forrásból származnak. Egyrészt a szerző felhasználja az European Parliamentary Research Group az EP-képviselők körében 2010-ben végzett kérdőíves adatfelvételének adatait, másrészt mindezt kiegészíti saját kérdőíves adatfelvételével, melyet 2011-12 során készített a közép-európai EP-képviselők körében. Mindez lehetővé teszi a közép-európai EP-képviselőkre vonatkozó eredmények vizsgálatát komparatív kontextusban, az EU15-ök viszonylatában is.

\section{KÉPVISELÓI SZEREPEK AZ EURÓPAI PARLAMENTBEN}

A képviselői szerepek kutatása újra reneszánszát éli a politikatudományban. Sokan sokféleképpen definiálják a szerepeket (Blomgren-Rozenberg, 2011; Searing, 1994; Strøm, 1997; Wahlke-Eulau-Buchanan-Ferguson, 1962), azonban egy dologban minden kutató egyetért: a szerepek fontosak, mert befolyásolják azt, hogy a képviselők milyen tevékenységeket folytatnak a parlamentekben, kiket képviselnek, és ennek milyen hatása van a demokratikus elszámoltatásra. A képviselet-irodalom ugyan kezdettől a nemzeti parlamentek képviselőit vizsgálja, az utóbbi években egyre gyakrabban jelennek meg olyan írások, amelyek az Európai Parlamentet helyezik a vizsgálat fókuszába (ld. pl. Farrell-Scully, 2010; Hausemer, 2006; Katz, 1997; Navarro, 2012; Scully-Farrell, 2003). A szakirodalom által felvázolt szerepeket, azonban - ahogy emellett Bíró-Nagy is érvel — nagyon nehéz az EP kontextusában értelmezni. A szupranacionális és kormányközi elemek keveredése, a „választási kapcsolat” hiánya (vagy legalábbis nem egyértelmú volta) és ebből fakadóan az újraválasztás motívumának gyengülése a képviselők motivációs rendszerén belül, a pártkormányzás hiánya, a konszenzusépítés előtérbe kerülése, a többszintú kormányzás, és a lehetséges karrier-állomások bonyolultabb kombinációi miatt újra kell értelmezni a képviselői szerepeket (Bíró-Nagy, 2018: 50-54.).

Az EP képviselői eleve két megbízó ügynökei (Hix, 2002), és ebből látszólag egyik sem a választó. Egyrészt az országonkénti választás és a pártok jelöltállításban játszott szerepe miatt a küldő párt vezetése jelentős hatást gyakorol a 
képviselők viselkedésére, másrészt az európai pártcsoport támogatása „jól megfogható előnyökkel járhat saját politikai előmenetelük szempontjából, az európai és a nemzeti politika szintjén egyaránt" (Bíró-Nagy, 2018: 101.). Az EP-képviselőknek tehát kétfelé kell figyelniük, egyensúlyt kell találniuk a két megbízó igényei és elvárásai között. A helyzetet ráadásul tovább bonyolítja, hogy az egyensúlyi helyzet időben nem állandó: akár szavazásról szavazásra változhat. Természetesen nem törvényszerủ az, hogy a két megbízó egymásnak feszül, hiszen adott esetben az európai pártcsoportban való előmenetel kedvezően hathat a képviselő pozíciójára a nemzeti pártban, viszont előfordul az is, hogy a képviselő két tűz közé kerül (Hix-Noury-Roland, 2007). Az, hogy az egyes képviselők esetében melyik megbízó bizonyul erősebbnek, közvetlen hatással van a képviselő által viselt szerepre és ezen keresztül a képviselő parlamenti és parlamenten kívüli tevékenységére. A téma kutatását az időbeli változáson túl tovább bonyolítja, hogy a két megbízó jelentősége képviselőről képviselőre is változik. Tehát túl kell lépnünk az intézményi-strukturális tényezők vizsgálatán akkor, ha fel szeretnénk tárni az EP-képviselők viselkedésének mozgatórugóit, és egyéni szinten kell vizsgálni a lehetséges motivációk bonyolult összevisszaságát.

Bíró-Nagy András a kérdőíves adatfelvételekre támaszkodva négy szereptípust különít el a képviselők attitúdjei mentén. Hangsúlyozandó, hogy ezek ideáltípusok, amelyek tiszta formában sosem jelennek meg a képviselók attitúdjeiben. Domináns és nem kizárólagos szerepekről van tehát szó, melyek azonban mégis jól elkülönítik egymástól a képviselők különböző csoportjait. A szerző hat változó segítségével alakítja ki a négy fő szereptípust. Figyelembe veszi a képviselet irányát (mennyire tartják fontosnak a jogalkotási munkát és a közös európai stratégiák kidolgozását), a képviselet fókuszát (mi a képviselők tevékenységének a területi fókusza: a saját ország állampolgárainak vagy Európa összes polgárának a képviselete) és a képviselők Európai Bizottsághoz füződő viszonyát (milyen intenzív kapcsolatokat ápolnak az Európai Bizottság hivatalnokaival és az uniós biztosokkal). Mindezek alapján az EPképviselők elhelyezhetők egy kétdimenziós koordináta-rendszerben, ahol az egyik tengely a szakpolitikai-politikai affinitást, a másik az európai-nemzeti törésvonalat fedi le. Ennek megfelelően a négy ideáltípus: (1) uniós szakpolitikusok, (2) nemzeti szakpolitikusok, (3) uniós politikusok és (4) nemzeti politikusok. A szereptípusok elhelyezkedését a koordináta-rendszerben az 1. ábra szemlélteti. 
1. ábra. Az EP-képviselők által betöltött szerepek

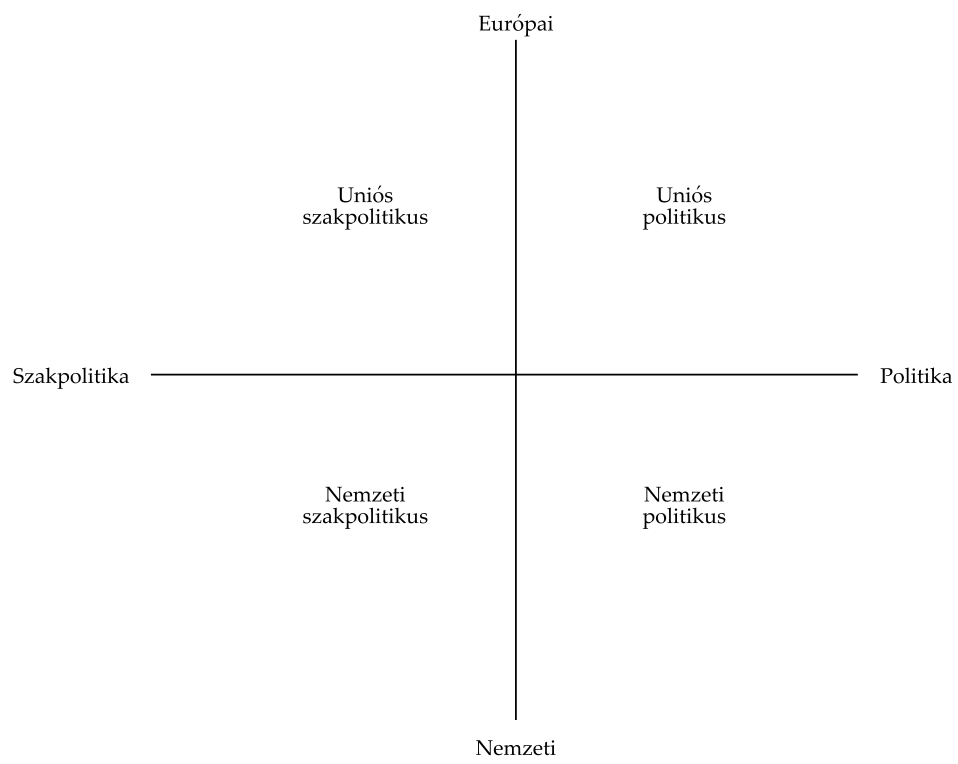

Az uniós szakpolitikusok azok a képviselők, akik az EU közpolitikai hatékonyságának megteremtését tartják legfőbb céljuknak, és ehhez európai szintú közpolitikai javaslatokat dolgoznak ki. Hasonló módon, de a küldő ország érdekeit szem előtt tartva tevékenykednek a nemzeti szakpolitikusok. A fentiekkel szemben az uniós politikusok nem szakpolitikai, hanem olyan politikai kérdésekkel foglalkoznak, amelyek az EU-t mint politikai egységet tekintik, és ennek védelmét célozzák meg. Végül, de nem utolsósorban a nemzeti politikusok célja a nemzeti érdekvédelem a politikai ügyekben. A közép-európai EP-képviselők 62\%-a uniós fókusszal bír, köztük is többségben vannak a szakpolitikusok (az összes közép-európai képviselő 38\%-a). A nemzeti orientációjú képviselők csoportjában is a szakpolitikai szempontok dominálnak (29\%), és a mintának mindössze 9\%-a tekinthető nemzeti politikusnak.

\section{BEFOLYÁSOLJA A KÉPVISELÓI SZEREPEKET?}

A képviselői szerepeket befolyásoló tényezők közül Bíró-Nagy kitüntetett figyelmet szentel a választási szabályoknak és a képviselői karrierutaknak. A választási szabályok közül talán a leghangsúlyosabb tényező a preferenciaszavazás megléte, magyarán az állampolgároknak az a képessége, hogy a szavazatukkal megváltoztassák a jelöltek sorrendjét a pártlistákon. A szakirodalomban előforduló népszerü hipotézis szerint azokban az országokban, ahol a 
választók személyekre is szavazhatnak, a képviselők szorosabb kapcsolatot tartanak az állampolgárokkal annak köszönhetően, hogy a választó markánsabban jelenik meg megbízóként a pártok mellett. Bíró-Nagy eredményei a közép-európai országokra vonatkozóan alátámasztják ezt a hipotézist. A képviselők Csehországban, Szlovákiában és Szlovéniában is intenzívebb kapcsolatokat ápolnak a választópolgárokkal, mint pl. Magyarországon.

A karrierutakat tekintve a képviselők aszerint különböztethetők meg leginkább, hogy milyen elképzeléseik vannak a karrierjük jövőbeli alakulásáról. Eszerint ismerünk „európai karrieristákat”, olyanokat, akik a nemzeti politikában képzelik el a jövőjüket, és olyanokat, akik a politikai karrierjük levezetésének tartják az EP-ben végzett munkájukat (Scarrow, 1997). Ez utóbbi kategória miatt nevezik gyakran a közbeszédben az EP-t „politikai elfekvőnek”, amely azonban nem is állhatna messzebb a valóságtól. A könyvben ismertetett eredmények alapján elmondható, hogy a visszavonuló képviselők kisebbségben vannak a közép-európai képviselők körében. A jövőbeli tervek azért is fontosak, mert megadják az EP-ben betöltött szerepek kereteit. A Szerző ugyanis empirikus összefüggést talál a karrierelképzelések és a képviselői szerepfelfogások között: az uniós fókusszal rendelkező képviselők az EU-n belül képzelik el karrierjük folytatását, míg a nemzeti fókuszúak nagyobb arányban ambicionálják a saját ország politikájába való visszatérést.

A képviselői szerepek két dimenzióját (uniós - nemzeti, közpolitikai - politikai) magyarázó modellek eltérő hatásokat fednek fel, amely eredmény tovább erősíti a két dimenzió elkülönítésének szükségességét. Az uniós szerepet az életkor, a pártcsalád, az ideológiai hovatartozás és az EP-szenioritás magyarázza, míg a politikusi szerep magyarázói között olyan tényezőket találunk, mint a helyi politikai tapasztalat, a jövőbeli politikai ambíciók és az EP-szenioritás. A nemzeti fókusszal szemben az uniós fókuszt erősíti a magasabb életkor, a baloldali orientáció, és gyengíti az EP-képviselői tapasztalat. A politikusi szerep dominanciáját a közpolitikusi szereppel szemben erősíti a helyi politikai tapasztalat mellett az EP-n belüli jövőkép, viszont csökkenti az EP-képviselői tapasztalat. Összességében a Bíró-Nagy által prezentált modellek jól leírják a csoportokhoz való tartozást, ami annak bizonyítéka, hogy a szerepek kialakítása valóban olyan struktúrák mentén történik, amelyek mind a stratégiákat, mind a motivációkat meghatározzák.

\section{MIBEN MUTATKOZNAK MEG A KÉPVISELŐI SZEREPEK?}

A parlamentek működése szempontjából talán az egyik legfontosabb kérdés az, hogy a szerepek, ha léteznek, akkor milyen következményekkel járnak. A könyvben tárgyalt fő kérdés az, hogy a különböző szerepek eltérő viselkedési mintákat eredményeznek-e mind a parlamenten kívül, mind a parlamen- 
ten belül. A parlamenten belüli tevékenységek leírása a legegyszerúbb, hiszen itt nyilvánosan elérhető adatokkal dolgozhatunk. A legkézenfekvőbb útnak a szavazási magatartás megfigyelése tû́nik. Az amerikai politikával szemben Európában az erős pártok és a rendkívüli pártfegyelem miatt ez igen kevés haszonnal kecsegtet, amikor a képviselők közötti különbségeket szeretnénk megmagyarázni (Thomassen-Andeweg, 2004). Ez alól az Európai Parlament sem kivétel. Az európai pártcsaládok amúgy is jelentős kohézióját az új országok csatlakozása - némileg a várttal ellentétben - még tovább erősítette, amiben nyilvánvalóan szerepe van az EP jogalkotó szerepe párhuzamos növelésének. A szavazói magatartásban tehát nem találunk olyan mintákat, amelyek a képviselői szerepek mentén alakulhatnak ki.

A képviselők munkájának a szavazással való azonosítása azonban meglehetősen túlhaladottnak számít a parlamenti kutatások irodalmában. Így tekint erre Bíró-Nagy is, és sorra veszi a képviselők rendelkezésére álló egyéb parlamenti múfajokat, mint a parlamenti felszólalás, állásfoglalási indítvány, parlamenti kérdés, írásbeli nyilatkozat (politikai múfajok), raportőri feladat, vélemény és módosító indítvány (közpolitikai múfajok). A közép-európai minta szintjén kimutatható, hogy a képviselői szerepek megjelennek a tevékenységek eloszlásában is. Míg a szakpolitikusok a politikai és közpolitikai múfajokban is legalább az átlag körül teljesítenek, addig a politikusok inkább a politikai múfajokra helyezik a hangsúlyt, és távol tartják magukat a közpolitikai tevékenységektől. A nemzeti politikusokra általános passzivitás jellemző: tevékenységük egyik múfajban sem éri el az átlagot. Ezzel szemben az uniós politikusok minden múfajban jobban teljesítenek, még a kifejezetten szakpolitikai tevékenységeket sem hanyagolják el annak ellenére, hogy nem kifejezetten vág a profiljukba.

Az EP-n kívüli tevékenységek vizsgálata az adathiány miatt ütközik nehézségekbe. Bíró-Nagy a kérdőíves kutatás adatait használja fel, mely az EPképviselők saját bevallása alapján jellemzi a képviselők kapcsolatait az EP-n kívüli politikai és nem politikai szereplőkkel. Az eredmények legfontosabb tanulsága, hogy az EP-n kívüli nem politikai aktorokkal fenntartott kapcsolatok tekintetében markáns különbség van a politikai-szakpolitikai tengely mentén. A szakpolitikusok azok, akiket a tartalmi eredmények elérése érdekében az állampolgárok, a szervezett érdekcsoportok, lobbisták és újságírók nagyobb arányban keresnek fel, mint a politikusokat. A külső politikai szereplők esetében és különösen az egyéb uniós szereplőkkel ápolt kapcsolatokban ismét megfigyelhető a nemzeti politikusok passzivitása. Továbbá némileg meglepőnek tûnik, hogy a nemzeti szakpolitikusok nem tartanak fent szorosabb kapcsolatokat a hazai szereplőkkel az uniós szakpolitikusokhoz képest, ami kifejezetten annak a jele, hogy az uniós szakpolitikusok (és általában az uniós politikusok) is fontosnak tartják az otthoni politikai szereplőkkel való jó viszony ápolását. 


\section{TOVÁBBIAK}

Mint minden nagy hatású tudományos munka, ez a kötet is felvet kérdéseket a jövőbeli kutatások számára. Véleményem szerint az egyik legfontosabb ezek közül a megbízó fogalmának újraértelmezése (vagy tágítása) az Európai Parlament esetében. Ahogy korábban már szó volt róla, az EP-képviselőkkel kapcsolatos kutatások alapvetően három kérdésre keresik a választ. (1) Mit tudható az EP-képviselők társadalmi-demográfiai hátteréről, és megkülönböztethetők-e speciális, az EP-képviselőkre jellemző karrierutak? (2) Milyen szereporientációk különíthetôk el? (3) Hogyan csapódnak le a szereporientációk az EP-képviselők viselkedésében? A parlamenti kutatások és ezzel párhuzamosan az EP-képviselőkkel foglalkozó kutatások az elmúlt években azonban felvetettek egy régi-új kérdést: milyen hatással bírnak a szerepek által meghatározott tevékenységek a képviselők választási prognózisára? Számít-e, hogy a képviselők mit csinálnak a parlamentben akkor, amikor a pártjuk az újrajelölésről dönt, illetve figyelembe veszik-e a választók a képviselők előző ciklusbeli teljesítményét, amikor leadják szavazatukat? Az Európai Parlament esetében ez utóbbi természetesen nem egyértelmú (Hix-Høyland, 2013; Hix et al., 2007). Azonban kétségtelen, hogy maga a tény, hogy az EU-tagországok jelentős részében flexibilis listákon állítják a jelölteket, felveti a kérdést, hogy ezekben az országokban megjelenik-e a választó is mint megbízó. Az Európai Parlamenttel foglalkozó szakirodalom már megtette a kezdő lépéseket ez irányba (ld. pl. Frech, 2016; Obholzer-Daniel, 2016; Sigalas, 2011; Thomme-RingeVictor, 2015; Wilson-Ringe-Thomme, 2016), ami tovább árnyalhatja a demokráciadeficittel kapcsolatos tudásunkat, és újabb megoldási lehetőségeket villanthat fel annak csökkentésére. Bíró-Nagy András könyve azért is különösen fontos ebből a szempontból, mert tudomásom szerint eleddig egy tudományos munka sem foglalkozott kifejezetten az újonnan csatlakozó országokkal, és ahhoz, hogy megértsük ezen országok EU-hoz való viszonyát, és gondolkozhassunk azon, hogy hogyan lehet közelebb hozni az EU-t a választókhoz, az első lépés az, hogy megértsük az EP főszereplőinek viszonyát saját képviselői szerepükhöz.

Összefoglalva, Bíró-Nagy András könyve minden bizonnyal számot tart kutatók, szakértők és egyetemi hallgatók érdeklődésére. Olyan hiánypótló munkának gondolom, amelyet minden Európai Unióval és parlamentekkel foglalkozó szakembernek ismernie kell. Követhetősége és könnyed stílusa miatt olyan, a téma iránt érdeklődő olvasóknak is ajánlom, akiknek nincs türelmük megküzdeni a tudományos szövegek gyakran életszerútlenül bonyolult nyelvezetével. 


\section{IRODALOM}

Bíró-Nagy A. (2018): Integráció Európába. Közép-európai képviselók az Európai Parlamentben. Budapest: Gondolat - MTA TK PTI.

Blomgren, M. - Rozenberg, O. (2011): Legislative roles and legislative studies. The neo-institutionalist turning point? In: Magnus Blomgren - Olivier Rozenberg (eds.): Parliamentary Roles in Modern Legislatures. London: Routledge, ECPR.

Farrell, D. M. - Scully, R. (2010): The European Parliament: one parliament, several modes of political representation on the ground? Journal of European Public Policy, 17 (1), 36-54. https://doi. org/10.1080/13501760903465173

Follesdal, A. - Hix, S. (2006): Why There is a Democratic Deficit in the EU: A Response to Majone and Moravcsik. JCMS: Journal of Common Market Studies, 44 (3), 533-62. https://doi.org/10.1111/ j.1468-5965.2006.00650.x

Frech, E. (2016): Re-electing MEPs: The factors determining re-election probabilities. European Union Politics, 17 (1), 69-90. https://doi.org/10.1177/1465116515615681

Hausemer, P. (2006): Participation and Political Competition in Committee Report Allocation: Under What Conditions Do MEPs Represent Their Constituents? European Union Politics, 7 (4), 505-30. https://doi.org/10.1177/1465116506069441

Hix, S. (2002): Parliamentary Behavior with Two Principals: Preferences, Parties, and Voting in the European Parliament. American Journal of Political Science, 46 (3), 688-98. https://doi. org/10.2307/3088408

Hix, S. - Høyland, B. (2013): Empowerment of the European Parliament. Annual Review of Political Science, 16 (1), 171-89. https://doi.org/10.1057/978-1-137-40709-2_2

Hix, S. - Noury, A. G. - Roland, G. (2007): Democratic Politics in the European Parliament. Cambridge - New York: Cambridge University Press.

Jahr, S. - Edinger, M. (2015): Making Sense of Multi-Level Parliamentary Careers: An Introduction. In: M. Edinger - S. Jahr (eds.): Political Careers in Europe. Career Patterns in Multi-Level Systems. New York: Bloomsbury.

Katz, R. S. (1997): Representational roles. European Journal of Political Research, 32 (2), 211-26. https:// doi.org/10.1111/1475-6765.00339

Lodge, J. (1994): The European Parliament and the Authority-Democracy Crises. The ANNALS of the American Academy of Political and Social Science, 531 (1), 69-83. https://doi.org/10.1177/ 0002716294531001006

Navarro, J. (2012): The cognitive rationality of role choices: evidence from the European Parliament. In: M. Blomgren - O. Rozenberg (eds.): Parliamentary Roles in Modern Legislatures. Oxon: Routledge.

Obholzer, L. - Daniel, W. T. (2016): An online electoral connection? How electoral systems condition representatives' social media use. European Union Politics, 17 (3), 387-407. https://doi. org/10.1177/1465116516630149

Scarrow, S. E. (1997): Political Career Paths and the European Parliament. Legislative Studies Quarterly, 22 (2), 253-63. https://doi.org/10.2307/440385 
Scully, R. - Farrell, D. M. (2003): MEPs as Representatives: Individual and Institutional Roles. JCMS: Journal of Common Market Studies, 41 (2), 269-88. https://doi.org/10.1111/1468-5965.00422

Searing, D. (1994): Westminster's World: Understanding political roles. Cambridge: Harvard University Press.

Sigalas, E. (2011): When quantity matters: Activity levels and re-election prospects of Members of the European Parliament. RECON Online Working Paper Series.

Strøm, K. (1997): Rules, Reasons and Routines: Legislative Roles in Parliamentary Democracies. In: W. C. Müller - Thomas Saalfeld (eds.): Members of Parliament in Western Europe. Roles and Behaviour. London: Frank Cass, 155-74.

Thomassen, J. - Andeweg, R. B. (2004): Beyond collective representation: individual members of parliament and interest representation in the Netherlands. The Journal of Legislative Studies, 10 (4), 47-69. https://doi.org/10.1080/1357233042000322463

Thomme, J. van - Ringe, N. - Victor, J. N. (2015): Explaining Reelection in the European elections 2014. Expertise, Influence, and Intergroups. In: M. Keading - N. Switek (eds.): Die Europawahl 2014. Spitzenkandidaten, Protestparteien, Nichtwähler. Springer.

Wahlke, J. C. - Eulau, H. - Buchanan, W. - Ferguson, L. C. (1962): The Legislative System. Explorations in Legislative Behavior. New York: Wiley.

Williams, S. (1991): Sovereignty and Accountability. In: R. O. Keohane - S. Hoffmann (eds.): The New European Community. Boulder, Colorado: Westview.

Wilson, S. L. - Ringe, N. - Thomme, J. van (2016): Policy leadership and re-election in the European Parliament. Journal of European Public Policy, 23 (8), 1158-79. https://doi.org/10.1080/135 01763.2016.1186213 